\title{
Generalist Bee Species on Brazilian Bee-Plant Interaction Networks
}

\author{
Astrid de Matos Peixoto Kleinert and Tereza Cristina Giannini \\ Ecology Department, University of São Paulo, 05508-900 São Paulo, SP, Brazil \\ Correspondence should be addressed to Tereza Cristina Giannini, giannini@usp.br \\ Received 3 February 2012; Accepted 19 March 2012 \\ Academic Editor: Felipe Andrés León Contrera
}

Copyright ( $) 2012$ A. M. P. Kleinert and T. C. Giannini. This is an open access article distributed under the Creative Commons Attribution License, which permits unrestricted use, distribution, and reproduction in any medium, provided the original work is properly cited.

\begin{abstract}
Determining bee and plant interactions has an important role on understanding general biology of bee species as well as the potential pollinating relationship between them. Bee surveys have been conducted in Brazil since the end of the 1960s. Most of them applied standardized methods and had identified the plant species where the bees were collected. To analyze the most generalist bees on Brazilian surveys, we built a matrix of bee-plant interactions. We estimated the most generalist bees determining the three bee species of each surveyed locality that presented the highest number of interactions. We found 47 localities and 39 species of bees. Most of them belong to Apidae (31 species) and Halictidae (6) families and to Meliponini (14) and Xylocopini (6) tribes. However, most of the surveys presented Apis mellifera and/or Trigona spinipes as the most generalist species. Apis mellifera is an exotic bee species and Trigona spinipes, a native species, is also widespread and presents broad diet breath and high number of individuals per colony.
\end{abstract}

\section{Introduction}

Bees are important keys to global diversity providing vital ecosystem services such as pollination [1]. For bees, plants species are basically their main food sources, where they collect pollen and nectar and eventually other resources, such as oil. Plants are those which have interest on bees' skills to achieve successful reproduction. They have to deal with different foraging techniques employed by bees [2-4] to reach their main reward, reproduction.

In Brazil, until the end of 1960s, information about beeplant interactions came mostly from observations made by naturalists of the early 20th century. However, the study of [5] proposed a standardized methodology to perform bee surveys that was subsequently applied to most of them, allowing further comparisons between the different surveyed localities.

The studies of [6-8] made previous synthesis of Brazilian surveys. The first one only compared information about species richness found in different biomes. The other two studies used only data from eusocial Apidae found on the surveys. Until now, no attempt was made to determine the generalist bee species in interaction networks of different localities using all Apoidea species found on them.

Interaction networks are built as a matrix of interacting species and have been justified mainly because networks involving plants and pollinators are generalists and form complex systems bringing additional challenges to their study [9].

In plant-pollinator interactions, species are commonly seen as generalists when they interact with many species of different taxa, and specialists if they interact with one or a few closely related species [10]. Reference [11] showed that in pollination systems the most generalized species are usually network keystone species. Since they interact with most plant species, they play an important role to maintain the whole network.

The main goal of this study was to determine the most generalist bee species on bee surveys conducted on different localities in Brazil.

\section{Material and Methods}

We searched the academic literature for bee surveys on flowering plants on different localities of Brazil, aiming to 


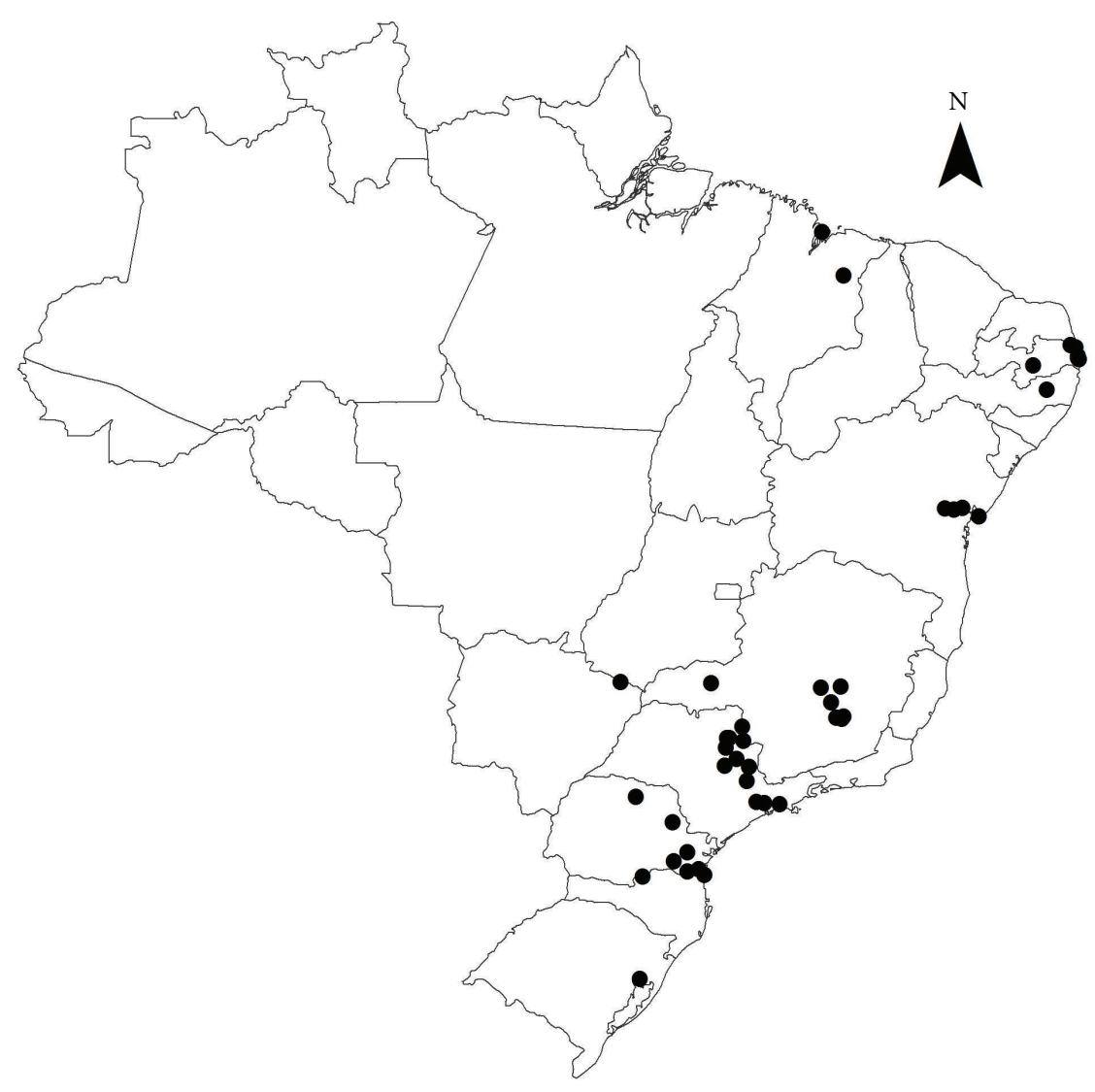

- Surveyed localities

Figure 1: Brazilian localities where the bee surveys were conducted.

build a matrix of bee-plant interactions to each locality. We considered the surveys that used the standard procedure suggested by [5] and whose observations were made for at least one year. In this procedure a fixed amount of time is spent at each flowering plant (or patch) and the coverage of transects is randomized in time, order, and direction. On most of these surveys, the interactions were not detailed and could include effective pollination and/or nectar, pollen, or oil foraging.

Many survey datasets have been published only in M.S. or Ph.D. thesis and are only available to the public at their universities. When these works were subsequently published as a paper, both datasets were compared and both were cited on the reference list.

The bee taxonomic names were updated according to [12]. We discarded the observations that were taxonomically unresolved.

We used the bipartite package [13] for R 2.11.1 (The $\mathrm{R}$ Foundation for Statistical Computing) to analyze each matrix. Each cell of the matrix represents a single bee-plant interaction and can have a value of 0 if the interaction is not observed, or 1, if observed [14]. With this tool we determined the first three bee species with the highest number of interactions.
The declared coordinate point of each survey was also used to build a map with ArcGIS 10 software (Esri Inc.).

\section{Results}

We found 47 localities whose surveys fulfilled the requirements previously quoted on the methodology section. Most surveys were done on South, Southeast, and Northeast regions of Brazil, either on urban areas, on seasonally dry areas of Tropical Dry Forest (Brazilian Caatinga) and Tropical Shrublands (Brazilian Cerrado), or on Tropical Moist Forest (Brazilian Atlantic Forest) biomes (Figure 1, Table 1). We did not find any bee survey on the North region and only one on the Midwest region of Brazil.

The first, second, and third most interacting species on each surveyed locality are found on Table 1 . We found a total number of 39 different species. Most of them belong to Apidae (31 species) and Halictidae (6) families, and to Meliponini (14) and Xylocopini (6) tribes (both from Apidae family). The genus with the highest number of interacting species was Xylocopa (5 species). The genera Trigona, Exomalopsis, and Augochloropsis presented each three interacting species. 


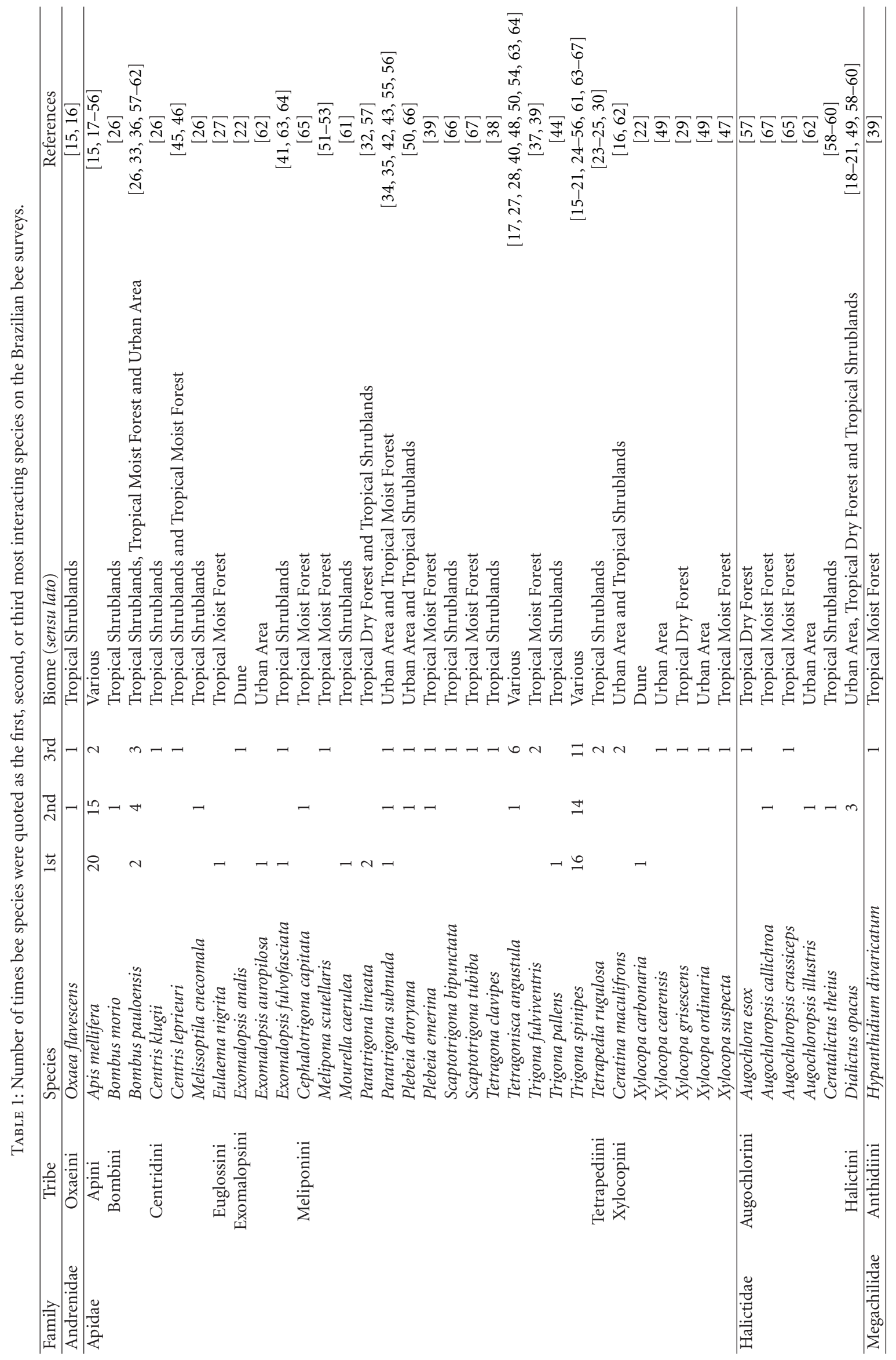




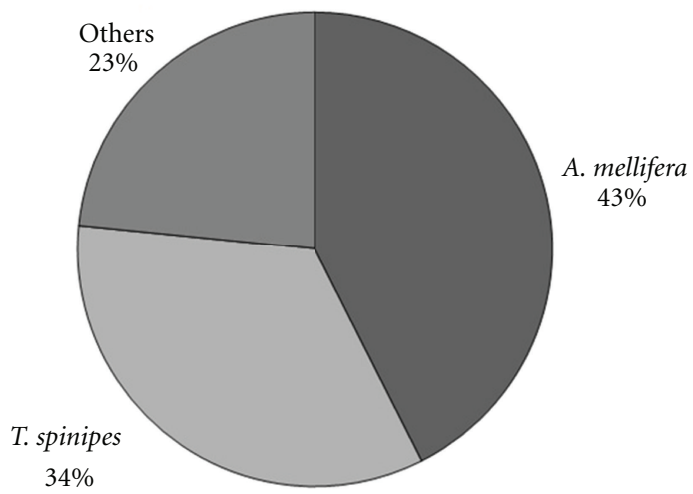

(a)

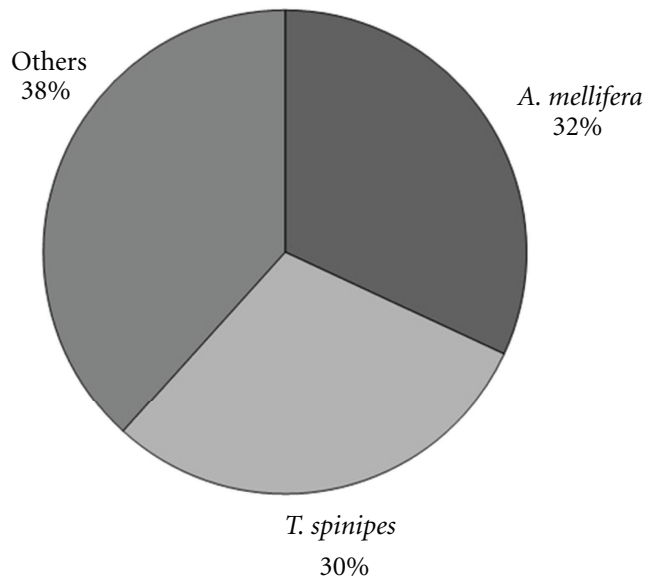

(b)

Figure 2: Percentage of Brazilian bee surveys presenting Apis mellifera or Trigona spinipes as (a) the first species with highest number of interactions and (b) the second species with highest number of interactions.

On most surveys Apis mellifera and/or Trigona spinipes were the most interacting species (Table 1). Considering the first and second species with the highest number of interactions, A. mellifera was present on $75 \%$ of the Brazilian surveys and T. spinipes on 64\% (Figure 2).

Other important interacting species were Bombus pauloensis that was quoted nine times on the different localities and on different ranks (first, second, or third interacting species), Tetragonisca angustula (7 times), Dialictus opacus, and Paratrigona subnuda (3 times each) (Table 1).

Halictidae and Xylocopini species as well as A. mellifera and T. spinipes were found on different biomes (Table 1). Most of Meliponini species were found on Tropical Moist Forest and on Tropical Shrublands.

\section{Discussion}

Apidae is a large family of bees, whose species are mostly generalist foragers. It is widely distributed, occurring on different biomes under different environmental characteristics [68]. Bee species from the Meliponini tribe live in tropical and subtropical regions of the world and are considered to be important pollinators of plant species on different environments [69].

T. spinipes, one of the most generalist stingless bee species according to our results, presents colonies with a huge number of individuals and wide diet breath, and it shows widespread distribution over the Brazilian territory. Moreover, they build aerial nests, being independent of any kind of holes to nidify. Independence of holes and the great availability of workers may determine the degree of dispersion over the countryside and the generalist interacting behavior [70].

A. mellifera is an exotic bee species also widespread in different biomes. It is well adapted to different climatic conditions and presents a generalist foraging behavior. Despite the potential negative impact on native pollinator species [71], it was already recognized as the most important pollinator of natural environments and also of agricultural crops [72].

Although we are not aware of any study comparing A. mellifera and T. spinipes pollinating performance, they are probably important resource competitors, due to their similar colony size and widespread distribution. The efficient communication system exhibited by Apis mellifera and the aggressive behavior on flowers, already reported to $T$. spinipes, complete this scenario [73, 74].

Recent reports of the colony collapse disorder syndrome of Apis mellifera species arouse the awareness of the importance of this species [75], especially due to its importance to agriculture. At the same time, it also brings the attention to the native pollinators and their importance to local crops, and international initiatives have been suggested to protect them [76].

Far from the number of interactions found for the two main species, two other generalist bee species were $B$. pauloensis (9 interactions) and T. angustula (7 interactions). Both species were found in distinct biomes, including urban areas, thus suggesting a broad ability to survive at different environmental conditions. But unlike T. spinipes both depend on cavities to nidify and do not present an efficient communication system as A. mellifera and its ability to leave for other places when conditions become hard [77], or the aggressive behavior on flowers reported to T. spinipes. Besides, their colonies are much smaller than those of these two species. All these factors together are responsible for the lower number of interactions presented by them in comparison to the two main species.

In summary, we demonstrated the importance of a native bee species ( $T$. spinipes) and of an exotic one ( $A$. mellifera) to interaction networks on surveys conducted in Brazil. As already mentioned, their populous colonies, broad distribution, and aggressive behavior probably are the most important contributors to these results. Comparisons involving their pollinating performance and resource 
partitioning are suggested as important lines for further research.

\section{Acknowledgment}

The authors wish to thank mainly the São Paulo Research Foundation (FAPESP) for financial support given to this work (2004/15801-0), which included a technical scholarship to Biol. Valdo da França Santos (2008/06704-1).

\section{References}

[1] G. C. Daily, Nature's Services: Societal Dependence on Natural Ecosystems, Island Press, Washington, DC, USA, 1997.

[2] F. C. Dyer, "The biology of the dance language," Annual Review of Entomology, vol. 47, pp. 917-949, 2002.

[3] J. C. Biesmeijer and E. J. Slaa, "Information flow and organization of stingless bee foraging," Apidologie, vol. 35, no. 2, pp. 143-157, 2004.

[4] J. C. Nieh, "Recruitment communication in stingless bees (Hymenoptera, Apidae, Meliponini)," Apidologie, vol. 35, no. 2, pp. 159-182, 2004.

[5] S. Sakagami, S. Laroca, and J. Moure, "Wild bee biocenotics in Sao Jose dos Pinhais (PR), South Brazil: preliminary report," Journal of the Faculty of Sciences Hokkaido University, vol. 16, no. 2, pp. 253-291, 1967.

[6] C. Pinheiro-Machado, I. Alves dos Santos, V. L. ImperatrizFonseca, A. M. P. Kleinert, and F. A. Silveira, "Brazilian bee surveys: state of knowledge, conservation and sustainable use," in Pollinating Bees, P. Kevan and V. L. Imperatriz-Fonseca, Eds., Ministry of Environment, Brasília, Brazil, 2002.

[7] J. Biesmeijer, E. J. Slaa, M. S. Castro, B. F. Viana, A. M. P. Kleinert, and V. L. Imperatriz-Fonseca, "Connectance of Brazilian social bee: food plant networks is influenced by habitat, but not by latitude, altitude or network size," Biota Neotropica, vol. 5, no. 1, pp. 85-93, 2005.

[8] J. C. Biesmeijer and E. J. Slaa, "The structure of eusocial bee assemblages in Brazil," Apidologie, vol. 37, no. 2, pp. 240-258, 2006.

[9] L. A. Burkle and R. Alarcón, “The future of plant-pollinator diversity: understanding interaction networks acrosss time, space, and global change," American Journal of Botany, vol. 98, no. 3, pp. 528-538, 2011.

[10] D. P. Vázquez and M. A. Aizen, "Asymmetric specialization: a pervasive feature of plant-pollinator interactions," Ecology, vol. 85, no. 5, pp. 1251-1257, 2004.

[11] A. M. Martín González, B. Dalsgaard, and J. M. Olesen, "Centrality measures and the importance of generalist species in pollination networks," Ecological Complexity, vol. 7, no. 1, pp. 36-43, 2010.

[12] J. S. Moure, D. Urban, and G. A. R. Melo, Catalogue of Bees (Hymenoptera, Apoidea) in the Neotropical Region, Sociedade Brasileira de Entomologia, Curitiba, Paraná, Brazil, 2007.

[13] C. F. Dormann, J. Fründ, N. Blüthgen, and B. Gruber, "Indices, graphs and null models: analyzing bipartite ecological networks," Open Ecology Journal, vol. 2, pp. 7-24, 2009.

[14] J. M. Olesen and P. Jordano, "Geographic patterns in plantpollinator mutualistic networks," Ecology, vol. 83, no. 9, pp. 2416-2424, 2002.

[15] S. R. Andena, L. R. Bego, and M. R. Mechi, "As comunidades de abelhas (Hymenoptera, Apoidea) de uma área de cerrado
(Corumbataí, SP) e suas visitas às flores," Revista Brasileira Zoociências, vol. 7, no. 1, pp. 55-91, 2005.

[16] M. J. O. Campos, Estudo das interações entre a comunidade de Apoidea, na procura de recursos alimentares, e a vegetação de cerrado da reserva de Corumbataí, SP, Ph.D. thesis, Universidade Federal de São Carlos, São Carlos, São Paulo, Brazil, 1989.

[17] K. Agostini and M. Sazima, "Plantas ornamentais e seus recursos para abelhas no campus da Universidade Estadual de Campinas, Estado de São Paulo, Brasil," Bragantia, vol. 62, no. 3, pp. 335-343, 2003.

[18] C. M. L. Aguiar, Abundância, diversidade e fenologia de abelhas (Hymenoptera-Apoidea) da caatinga (São João do Cariri, PB) e suas interações com a flora apícola, M.S. thesis, Universidade Federal da Paraíba, João Pessoa, Brazil, 1995.

[19] C. M. L. Aguiar and C. F. Martins, "Abundância relativa, diversidade e fenologia de abelhas (Hymenoptera, Apoidea) na Caatinga, São João do Cariri, Paraíba, Brasil," Iheringia, vol. 83, pp. 151-163, 1997.

[20] C. M. L. Aguiar, "Utilização de recursos florais por abelhas (Hymenoptera: Apoidea) em uma área de Caatinga (Itatim, Bahia, Brasil)," Revista Brasileira de Zoologia, vol. 20, no. 3, pp. 457-467, 2003.

[21] C. M. L. Aguiar and F. C. V. Zanella, "Estrutura da comunidade de abelhas (Hymenoptera: Apoidea: Apiformis) de uma área na margem do domínio da Caatinga (Itatim, BA)," Neotropical Entomology, vol. 34, no. 1, pp. 15-24, 2005.

[22] P. M. C. Albuquerque, Abelhas silvestres (Hymenoptera, Apoidea) e suas fontes de alimento em um ecossistema de dunas, na ilha do Maranhão, MA, Brasil: composição, fenologia e interações, Ph.D. thesis, Universidade de São Paulo, Riberão Preto, São Paulo, Brazil, 1998.

[23] D. Almeida, Espécies de abelhas (Hymenoptera, Apoidea) e tipificação dos méis por elas produzidos em área de Cerrado do município de Pirassununga, Estado de São Paulo, M.S. thesis, Universidade de São Paulo, Piracicaba, São Paulo, Brazil, 2002.

[24] D. A. Almeida and L. C. Marchini, "Análise faunística de abelhas (Hymenoptera, Apoidea) coletadas no cerrado do Estado de São Paulo," Maringá, vol. 27, no. 3, pp. 277-284, 2005.

[25] A. C. C. C. Moreti, D. A. Anacleto, M. D’Avila, G. H. C. Vieira, and L. C. Marchini, "Abelhas visitantes em vegetação de diferentes áreas remanescentes de cerrado," Magistra, vol. 18, no. 4, pp. 229-248, 2006.

[26] V. A. Araújo, Y. Antonini, and A. P. A. Araújo, "Diversity of bees and their floral resources at altitudinal areas in the Southern Espinhaço Range, Minas Gerais, Brazil," Neotropical Entomology, vol. 35, no. 1, pp. 30-40, 2006.

[27] C. A. L. Carvalho, Abelhas (Hymenoptera, Apoidea) no município Cruz das Almas-Bahia: levantamento, identificação e material coletado em plantas de importância econômica, M.S. thesis, Universidade Federal da Bahia, Salvador, Bahia, Brazil, 1993.

[28] C. A. L. Carvalho, O. M. Marques, and H. S. V. Sampaio, "Abelhas (Hymenoptera, Apoidea) em Cruz das AlmasBahia: 1. Espécies coletadas em fruteiras," Insecta, vol. 4, no. 1, pp. 11-17, 1995.

[29] C. A. L. Carvalho, Diversidade de abelhas (Hymenoptera, Apoidea) e plantas visitadas no município de Castro Alves-BA, Ph.D. thesis, Universidade de São Paulo, Piracicaba, São Paulo, Brazil, 1999.

[30] M. D’Avila, Insetos visitantes florais em áreas de cerradão e cerrado sensu stricto no Estado de São Paulo, Ph.D. thesis, Universidade de São Paulo, Piracicaba, São Paulo, Brazil, 2006. 
[31] G. M. Faria, A flora e a fauna apícola de um ecossistema de campo rupestre, Serra do Cipó-MG, Brasil: Composição, fenologia e suas interações, Ph.D. thesis, Universidade de São Paulo, São Paulo, São Paulo, Brazil, 1994.

[32] G. M. Faria-Mucci, M. A. Melo, and L. A. O. Campos, "A fauna de abelhas (Hymenoptera, Apoidea) e plantas utilizadas como fonte de recursos florais, em um ecossistema de campos rupestres em Lavras Novas, Minas Gerais, Brasil," in Apoidea Neotropica: Homenagem aos 90 anos de Jesus Santiago Moure, G. R. Melo and I. Alves-dos-Santos, Eds., UNESC, Criciúma, Santa Catarina, Brazil, 2003.

[33] L. Freitas, Biologia da Polinização em Campos de Altitude no Parque Nacional da Serra da Bocaina, SP, Ph.D. thesis, Universidade Estadual de Campinas, Campinas, São Paulo, Brazil, 2002.

[34] F. R. N. Knoll, Abundância relativa, sazonalidade e preferências florais de Apidae em uma área urbana $\left(23^{\circ} 33^{\prime} \mathrm{D} ; 46^{\circ} 43^{\prime} \mathrm{W}\right)$, Ph.D. thesis, Universidade de São Paulo, São Paulo, São Paulo, Brazil, 1990.

[35] F. R. N. Knoll, L. R. Bego, and V. L. Imperatriz-Fonseca, "Abelhas em áreas urbanas. Um estudo no Campus da Universidade de São Paulo," in Flores e abelhas em São Paulo, J. R. Pirani and M. Cortopassi-Laurino, Eds., EDUSP, São Paulo, São Paulo, Brazil, 1993.

[36] C. Krug, A comunidade de abelhas (Hymenoptera: Apiformes) da Mata com Araucária em Porto União-SC e abelhas visitantes florais da aboboreira (Cucurbita L.) em Santa Catarina, com notas sobre Peponapis fervens (Eucerini, Apidae), M.S. thesis, Universidade do Extremo Sul Catarinense, Criciúma, Santa Catarina, Brazil, 2007.

[37] M. F. C. Lima, Comunidade de abelhas, nidificação de abelhas solitárias em cavidades preexistentes (Hymenoptera: Apoidea) e interação abelha-planta na Reserva Biológica Guaribas, Mamanguape, Paraíba, Brasil, Ph.D. thesis, Universidade Federal da Paraíba, João Pessoa, Paraíba, Brazil, 2004.

[38] S. Mateus, Abundância relativa, fenologia e visita às flores pelos Apoidea do cerrado da Estação Ecológica de Jataí-Luiz Antônio-SP, M.S. thesis, Universidade de São Paulo, Ribeirão Preto, São Paulo, Brazil, 1998.

[39] D. M. D. S. Mouga, As comunidades de abelhas (Hymenoptera, Apoidea) em Mata Atlântica na região nordeste do Estado de Santa Catarina, Brasil,, Ph.D. thesis, Universidade de São Paulo, São Paulo, São Paulo, Brazil, 2004.

[40] F. H. Nogueira-Ferreira and S. C. Augusto, "Amplitude de nicho e similaridade no uso de recursos florais por abelhas eusociais em uma área de Cerrado," Bioscience Journal, vol. 23, no. 1, pp. 45-51, 2007.

[41] S. R. M. Pedro, Sobre as abelhas (Hymenoptera, Apoidea) em um ecossistema de cerrado (Cajuru, NE do Estado de São Paulo): composição, fenologia e visita às flores, M.S. thesis, Universidade de São Paulo, Ribeirão Preto, São Paulo, Brazil, 1992.

[42] M. Ramalho, Diversidade de abelhas (Apoidea, Hymenoptera) em um remanescente de floresta atlântica em São Paulo, Ph.D. thesis, Universidade de São Paulo, São Paulo, São Paulo, Brazil, 1995.

[43] M. Ramalho, "Stingless bees and mass flowering trees in the canopy of Atlantic Forest: a tight relationship," Acta Botanica Brasilica, vol. 18, no. 1, pp. 37-47, 2004.

[44] M. M. C. Rêgo, Abelhas silvestres (Hymenoptera, Apoidea) em um ecossistema de cerrado s.l. (Chapadinha - MA, Brasil): uma abordagem biocenótica, Ph.D. thesis, Universidade de São Paulo, Ribeirão Preto, São Paulo, Brazil, 1998.

[45] M. C. M. Silva, Estrutura da comunidade de abelhas (Hymenoptera, Apoidea) de uma área de restinga (Praia de
Intermares, Cabedelo, Paraíba, Nordeste do Brasil), Ph.D. thesis, Universidade Federal da Paraíba, João Pessoa, Paraíba, Brazil, 1998.

[46] M. C. M. Silva and C. F. Martins, "Flora apícola e relações tróficas de abelhas (Hymenoptera, Apoidea) em uma área de restinga (Praia de Intermares, Cabedelo-PB, Brasil)," Principia, vol. 7, pp. 40-51, 1999.

[47] M. C. M. Silva, Fauna de abelhas (Hymenoptera, Apoidea, Apiformes) em hábitats de restinga na Área de Proteção Ambiental da Barra do Rio Mamanguape, PB, Brasil: Abundância, diversidade, sazonalidade e interações com as plantas, Ph.D. thesis, Universidade Federal da Paraíba, João Pessoa, Paraíba, Brasil, 2004.

[48] F. A. Silveira, Abelhas silvestres (Hymenoptera: Apoidea) e suas fontes de alimento no cerrado da estação florestal de experimentação de Paraopeba-Minas Gerais, M.S. thesis, Universidade Federal de Viçosa, Viçosa, Minas Gerais, Brazil, 1989.

[49] M. S. Silveira, Fauna de abelhas (Hymenoptera, Apoidea, Apiformes) e recursos florais utilizados em áreas urbanas e no entorno da cidade de João Pessoa, PB, M.S. thesis, Universidade Federal da Paraíba, João Pessoa, Paraíba, Brazil, 2006.

[50] S. H. Sofia, As abelhas e suas visitas às flores em duas áreas urbanas, Ph.D. thesis, Universidade Estadual Paulista, Rio Claro, São Paulo, Brazil, 1996.

[51] E. M. L. Souza, Fenologia e relações abelhas/plantas em uma comunidade de Mata Serrana (Brejo de Altitude) no nordeste do Brasil,, Ph.D. thesis, Universidade Federal de Pernambuco, Recife, Pernambuco, Brazil, 2003.

[52] E. Locatelli and I. C. Machado, "Bee diversity and their floral resources in a fragment of a Tropical Altitudinal Wet Forest (Brejos de Altitude) in Northeastern Brazil," Acta Horticulturae, vol. 561, pp. 317-326, 2001.

[53] E. Locatelli, I. C. Machado, and P. Medeiros, "Riqueza de abelhas e a flora apícola em um fragmento de Mata Serrana (Brejo de Altitude) em Pernambuco, Nordeste do Brasil," in Brejos de Altitude em Pernambuco e Paraíba: História Natural, Ecologia e Conservação, K. C. Porto, J. J. P. Cabral, and M. Tabarelli, Eds., Ministério do Meio Ambiente, Brasília, Goiás, Brazil, 2004.

[54] G. H. C. Vieira, Análise faunistica de abelhas (Hymenoptera: Apoidea) e tipificação dos méis produzidos por Apis mellifera L., em área de cerrado no município de Cassilândia/MS, Ph.D. thesis, Universidade de São Paulo, Piracicaba, São Paulo, Brazil, 2005.

[55] W. Wilms, Die Bienenfauna im Küstenregenwald Braziliens und ihre Beziehungen zu Blütenpflanzen: Fallstudie Boracéia, São Paulo, Ph.D. thesis, Universität Tübingen, Tübingen, Germany, 1995.

[56] W. Wilms, V. L. Imperatriz-Fonseca, and W. Engels, "Resource partitioning between highly eusocial bees and possible impact of the introduced Africanized honey bee on native stingless bees in the Brazilian atlantic rainforest," Studies on Neotropical Fauna and Environment, vol. 31, no. 3-4, pp. 137-151, 1996.

[57] Y. Antonini and R. P. Martins, "The flowering-visiting bees at the ecological station of the universidade federal de Minas Gerais, Belo Horizonte, MG, Brazil," Neotropical Entomology, vol. 32, no. 4, pp. 565-575, 2003.

[58] I. F. Barbola, A comunidade de Apoidea (Hymenoptera) da reserva Passa Dois (Lapa, Paraná): Diversidade, fenologia e relações tróficas, M.S. thesis, Universidade Federal do Paraná, Curitiba, Paraná, Brazil, 1993.

[59] I. Barbola and S. Laroca, "A comunidade de Apoidea (Hymenoptera) da Reserva Passa Dois (Lapa, Paraná, Brasil). 
I. Diversidade, abundância relativa e atividade sazonal," Acta Biologica Paranaense, vol. 22, no. 1-4, pp. 91-113, 1993.

[60] I. F. Barbola, S. Laroca, and M. C. Almeida, "Utilização de recursos florais por abelhas silvestres (Hymenoptera, Apoidea) da Floresta Estadual Passa Dois (Lapa, Paraná, Brasil)," Revista Brasileira de Entomologia, vol. 44, no. 1/2, pp. 9-19, 2000.

[61] M. Hoffmann, Estrutura e importância de uma comunidade de abelhas (Hymenoptera: Apoidae) no Rio Grande do Sul, para a polinização de plantas cultivadas, Ph.D. thesis, Universidade Federal do Paraná, Curitiba, Paraná, Brazil, 1990.

[62] J. M. F. Camargo and M. Mazucato, "Inventário da apifauna e flora apícola de Ribeirão Preto, SP Brasil,”, Dusenia, vol. 14, no. 2, pp. 55-87, 1984.

[63] A. M. C. Carvalho, Estudo das interações entre a apifauna e a flora apícola em vegetacão de cerrado-Reserva Ecológica do Panga-Uberlândia-MG, M.S. thesis, Universidade de São Paulo, Ribeirão Preto, São Paulo, Brazil, 1990.

[64] A. M. C. Carvalho and L. R. Bego, "Studies on Apoidea fauna of cerrado vegetation at the Panga Ecological Reserve, Uberlândia, MG, Brazil," Revista Brasileira de Entomologia, vol. 40, no. 2, pp. 147-156, 1998.

[65] J. R. Cure, G. S. Basto-Filho, M. J. F. Oliveira, and F. A. Silveira, "Levantamento de abelhas silvestres na zona da mata de Minas Gerais I-pastagem na região de Viçosa (HymenoperaApoidea)," Ceres, vol. 40, no. 228, pp. 131-161, 1993.

[66] S. Laroca and M. C. Almeida, "O relicto de cerrado de Jaguariaíva, (Paraná, Brasil): padrões biogeográficos, melissocenosses e flora melissófila," Acta Biologica Paranaense, vol. 23, no. 1/4, pp. 89-122, 1994.

[67] F. M. Santos, Fenologia e estrutura de comunidade de abelhas (Hymenoptera: Apoidea) visitante de flores do município de Esperantina, Estado do Tocantins, M.S. thesis, Universidade Federal da Bahia, Salvador, Bahia, Brazil, 2003.

[68] C. D. Michener, The Bees of the World, Johns Hopkins, 2007.

[69] T. A. Heard, "The role of stingless bees in crop pollination," Annual Review of Entomology, vol. 44, pp. 183-206, 1999.

[70] M. Cortopassi-Laurino and M. Ramalho, "Pollen harvest by Africanized Apis mellifera and Trigona spinipes in São Paulo: botanical and ecological views," Apidologie, vol. 19, pp. 1-24, 1988.

[71] D. W. Roubik, "Competitive interactions between neotropical pollinators and Africanized honey bees," Science, vol. 201, no. 4360, pp. 1030-1032, 1978.

[72] S. G. Potts, J. C. Biesmeijer, C. Kremen, P. Neumann, O. Schweiger, and W. E. Kunin, "Global pollinator declines: trends, impacts and drivers," Trends in Ecology and Evolution, vol. 25, no. 6, pp. 345-353, 2010.

[73] L. C. Minussi and I. Alves-dos-Santos, "Abelhas nativas versus Apis mellifera Linnaeus, especie exotica (Hymenoptera: Apidae)," Bioscience Journal, vol. 23, no. 1, pp. 58-62, 2007.

[74] J. C. Nieh, K. Kruizinga, L. S. Barreto, F. A. L. Contrera, and V. L. Imperatriz-Fonseca, "Effect of group size on the aggression strategy of an extirpating stingless bee, Trigona spinipes," Insectes Sociaux, vol. 52, no. 2, pp. 147-154, 2005.

[75] E. Stokstad, "The case of the empty hives," Science, vol. 316, no. 5827, pp. 970-972, 2007.

[76] B. Dias, A. Raw, and V. L. Imperatriz-Fonseca, International Pollinators Initiative: the São Paulo Declaration on Pollinators, Brazilian Ministry of the Environment, Brasília, Brazil, 1999.

[77] C. D. Michener, “The Brazilian honeybee," BioScience, vol. 23, no. 9, pp. 523-527, 1973. 

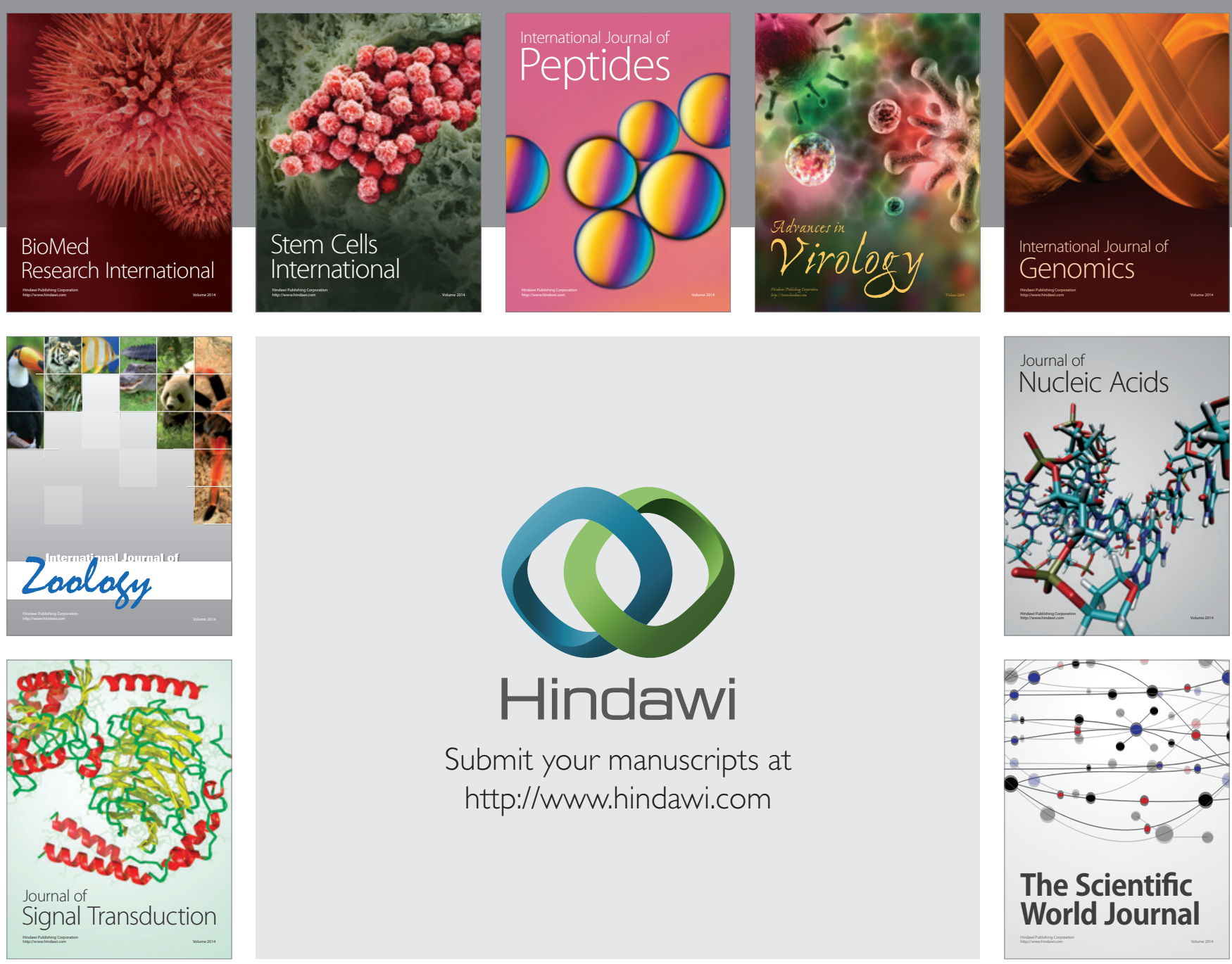

Submit your manuscripts at

http://www.hindawi.com
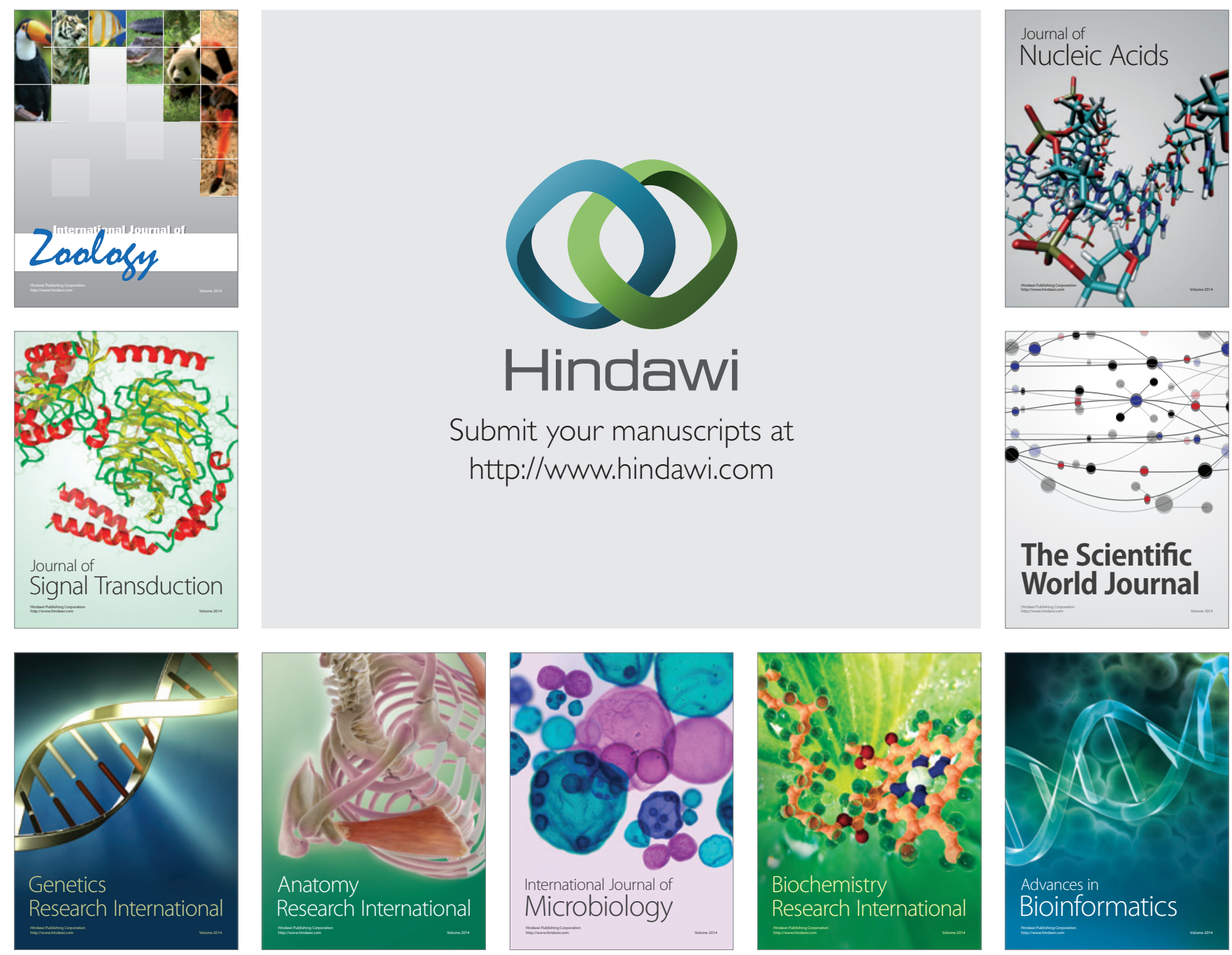

The Scientific World Journal
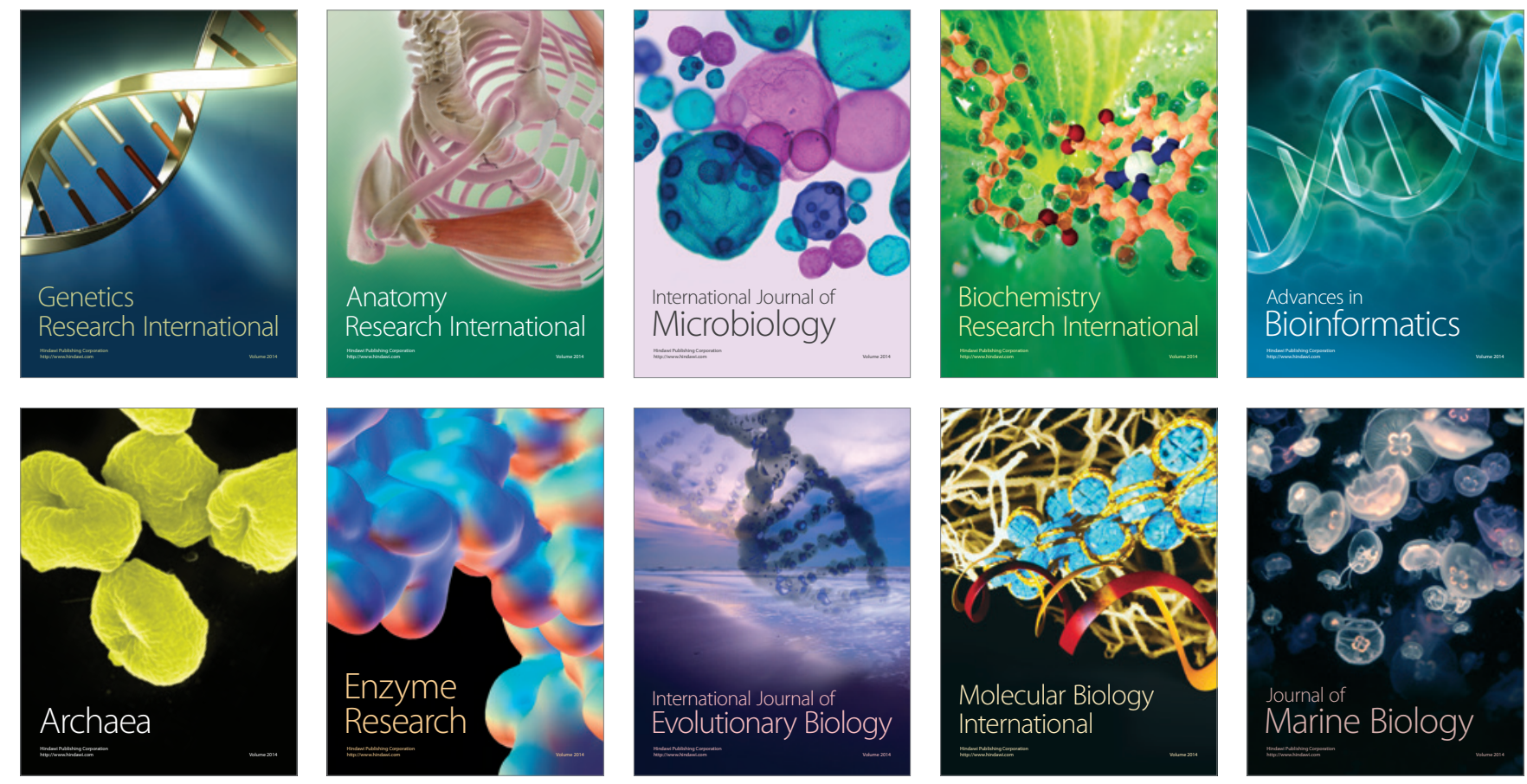